\title{
Microcystic Renal Disease
}

National Cancer Institute

\section{Source}

National Cancer Institute. Microcystic Renal Disease. NCI Thesaurus. Code C103918.

A cong enital renal disorder characterized by the presence of small cysts in the renal cortex and/or renal medulla. 